\title{
Dynamic synergies between China's Belt and Road Initiative and the UN's Sustainable Development Goals
}

\author{
Donald J. Lewis ${ }^{1,2}$, \\ Xiaohua Yang ${ }^{2}$, Diana Moise ${ }^{3}$ \\ and Stephen John Roddy ${ }^{4}$
}

\footnotetext{
${ }^{1}$ China University Political Science and Law, 27 Fuxue Road, Changping District, Beijing 102249, China; ${ }^{2}$ China Business Studies Initiative (CBSI), School of Management, University of San Francisco, 2130 Fulton St, Malloy Hall, San Francisco, CA 94118, USA; ${ }^{3}$ Debevoise \& Plimpton LLP, 65 Gresham St, London EC2V 7NQ, $U K ;{ }^{4}$ Department of Modern and Classical Languages, University of San Francisco, San Francisco, CA 94118, USA

\section{Correspondence:}

DJ Lewis, China University Political Science and Law, 27 Fuxue Road, Changping District, Beijing 102249, China

e-mail: dlewis4@usfca.edu
}

\begin{abstract}
This study examines the dynamic evolving synergies between the UN's Sustainable Development Goals (SDGs) and China's Belt and Road Initiative (BRI). This is among the first studies to present an in-depth comparative treatment and evaluation of these monumental change-oriented undertakings in terms of their interlinks, complementarities, and synergistic potential to mobilize and transform public policy and managerial decision-making in the pursuit of sustainable development. In our study, we identify BRI focus areas, goals, and modalities and explore their manifold interactions with the 17 SDGs, including by reference to dozens of recent BRI and AIIB projects. Our findings strongly suggest ongoing alignment and convergence between the SDGs and BRI, as exemplified by the recent overt inclusion of BRI within the UN's 2030 Agenda. However, realization of such promising synergies hinges on several variables, including the geopolitical and public health environments, the adoption of more holistic trade and investment strategies, and greater openness and inclusiveness towards non-Chinese and local businesses, particularly regarding their participation in BRI sustainable infrastructure investment projects. Public policy efforts will be essential to steer BRI in more open, liberal, and integrative directions so that BRI can function optimally as an effective vehicle for achievement of the SDGs.
\end{abstract}

Journal of International Business Policy (2021) 4, 58-79.

https://doi.org/ | 0. I 057/s422 I 4-020-00082-6

Keywords: Sustainable Development Goals; UN 2030 Agenda; Belt and Road Initiative; BRI-SDGS; infrastructure investment; sustainable investment; ecological civilization

\section{INTRODUCTION}

In 2013, the United Nations established a special working group to formally develop the Sustainable Development Goals (SDGs) in order to guide UN Member countries embarking on the path of sustainable development (Geng, 2015). This groundbreaking work on the SDGs subsequently led in 2015 to formal adoption by the United Nations General Assembly of the 2030 Agenda for Sustainable Development and promulgation of the $17 \mathrm{SDGs},{ }^{1}$ a monumental multilateral initiative representing a continuum which was preceded, inter alia, by the Millennium Development Goals (MDGs) launched in 2000.
Received: 25 May 2019

Revised: 8 October 2020

Accepted: 15 October 2020

Online publication date: 21 January 2021 
In the fall of 2013, Chinese President Xi Jinping proposed the Belt and Road Initiative (BRI) when he visited Central Asia and Southeast Asia. The BRI aims to strengthen interconnectivity between countries along the land-based Silk Road Economic Belt and 21st Century Maritime Silk Road, while at the same time promoting sustainable social and economic development amongst all BRI countries (Lewis \& Moise, 2018).

At first glance, China's Belt and Road Initiative and the UN 2030 Agenda for Sustainable Development are separate processes. However, on closer examination, it becomes apparent that there is considerable overlap in goals and strategies, as well as in-depth coordination, informing these two monumental international change-oriented undertakings. Some initial research suggests such intentional alignment of BRI goals with SDGs is evident in certain BRI countries (Feng, Kang, Pan, \& Yang, 2019). Each of these undertakings is potentially mutually reinforcing so that BRI holds great promise to serve as a vehicle for the attainment of the SDGs across critical regions of Asia and Africa by 2030 , and, in turn, the 17 SDGs may potentially provide legitimizing grounds for BRI.

In this paper, we take note of the inherent compatibility and synergistic convergence between BRI and the SDGs, and argue that the influence of SDGs on BRI is becoming increasingly apparent in the roll-out of projects. The overt inclusion of BRI within the UN's 2030 Agenda (formalized in 2017) cements the institutional groundwork for this development, with implications for future studies of the dynamic interplay between these two megainitiatives and the role that international business can play in this process. Such institutionalization is especially evident in the BRI-SDGS Project, which is being spearheaded by the United Nations Department of Economic and Social Affairs (DESA) and by UNESCAP in Asia Pacific, discussed in detail later.

In sum, we argue that BRI-SDGS and other landmark projects that stem from a series of policy decisions and bilateral or multilateral discussions have created momentum for the convergence of these two globe-shifting initiatives. In the following sections, we present accounts of how BRI implementation can, and in many cases has already, actualized multiple SDGs. We also raise criticisms based on some of the inconsistencies, shortcomings, and potential failures of BRI projects in living up to the goals of sustainability, and suggest how they can be rectified with openness and inclusiveness through multilateral and other efforts. Finally, we note that the convergence of BRI with SDGs may be buttressed by China's commitment to achieving ecological civilization, as articulated in various policy statements, macroeconomic plans, and regulatory regimes (Hanson, 2019).

\section{INTERLINKS BETWEEN SDGS AND BRI}

It is noted that both BRI and the SDGs give priority to solving the basic problems of poverty alleviation, health, education, and employment that constitute the main concerns of today's global population. BRI construction covers eight major areas, including infrastructure, economic and trade cooperation, industrial investment, resource development, financial cooperation, cultural exchanges, marine cooperation, and ecological protection. Many of the goals and targets of the 2030 Agenda for Sustainable Development are closely related to these eight BRI areas. For example, SDG Goal 7 involves renewable energy, SDG Goal 9 pertains to infrastructure, SDG Goals 8 and 10 concern trade and finance, SDG Goal 14 deals with oceans and marine ecology, and, importantly, SDG Goal 17 encourages a range of partnerships to implement and achieve these goals (Hong, 2016). This suggests that achieving the above-mentioned BRI agenda would lead to fulfilling at least part of the UN 2030 Agenda.

In particular, the five focus or priority areas of the Belt and Road Initiative, viz., policy communication, facilities connectivity, unimpeded trade, financial intermediation and people-to-people bonds, appear to promote the 17 SDGs (see Table 1). For example, facilities connectivity will directly contribute to the achievement of SDGs concerning poverty alleviation, the promotion of sustained, inclusive development, and the construction of disaster-resilient infrastructure.

The BRI focus on infrastructure is particularly relevant for attaining the SDGs. As identified since 2014, the investment gaps in the key SDG sectors pertain to power (requiring electricity and energy infrastructure), transport (requiring roads, railways, and ports), telecommunications (requiring broadband networks and other IT infrastructure), climate change (requiring green energy investments), and health or education (both requiring appropriate buildings and transport connections) (UNCTAD, 2014). These gaps fall precisely within BRI's ambit (Sheng, 2020), as Table 1 also shows. Moreover, the financial institutions backing the initiative have a 


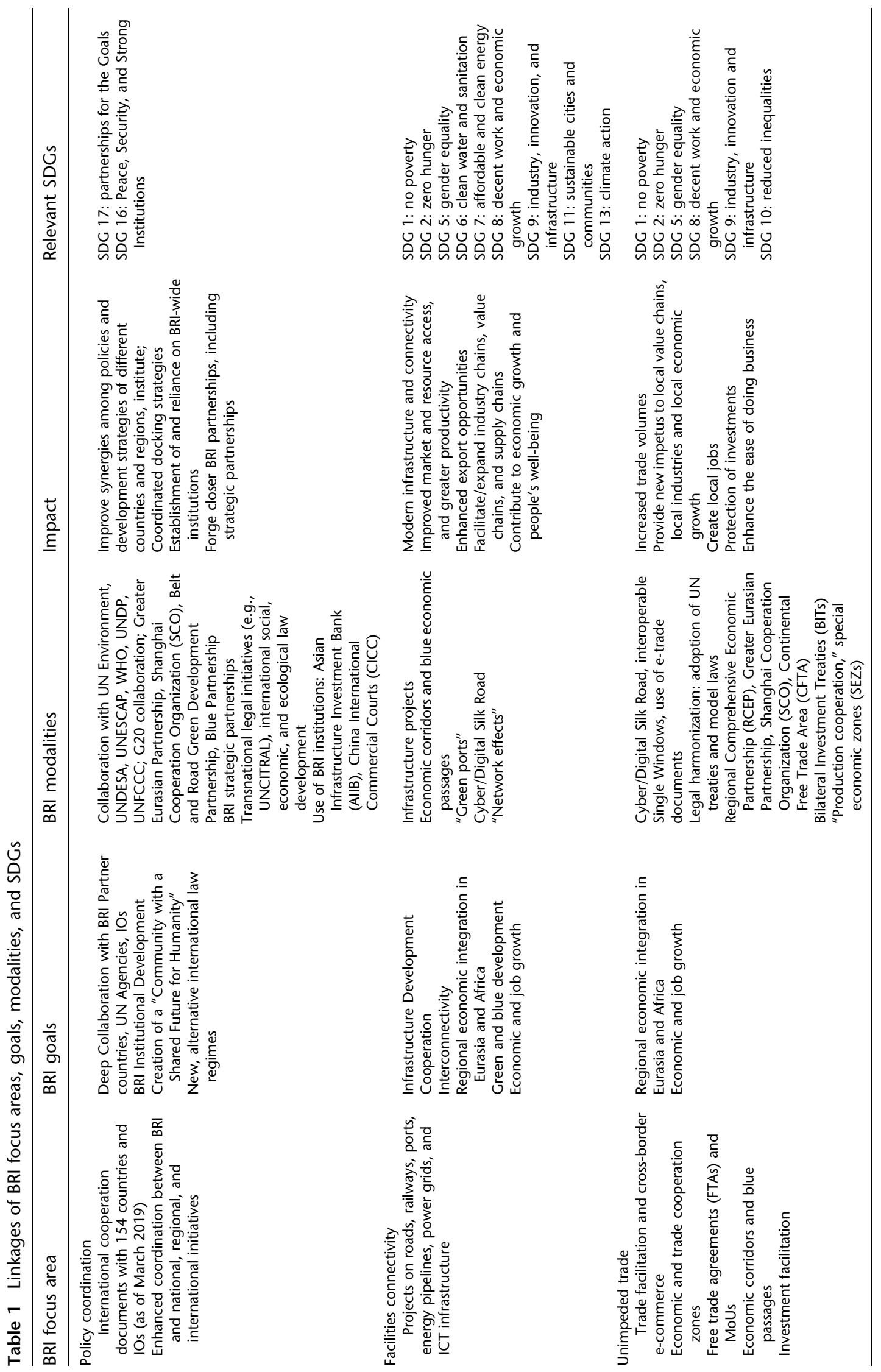




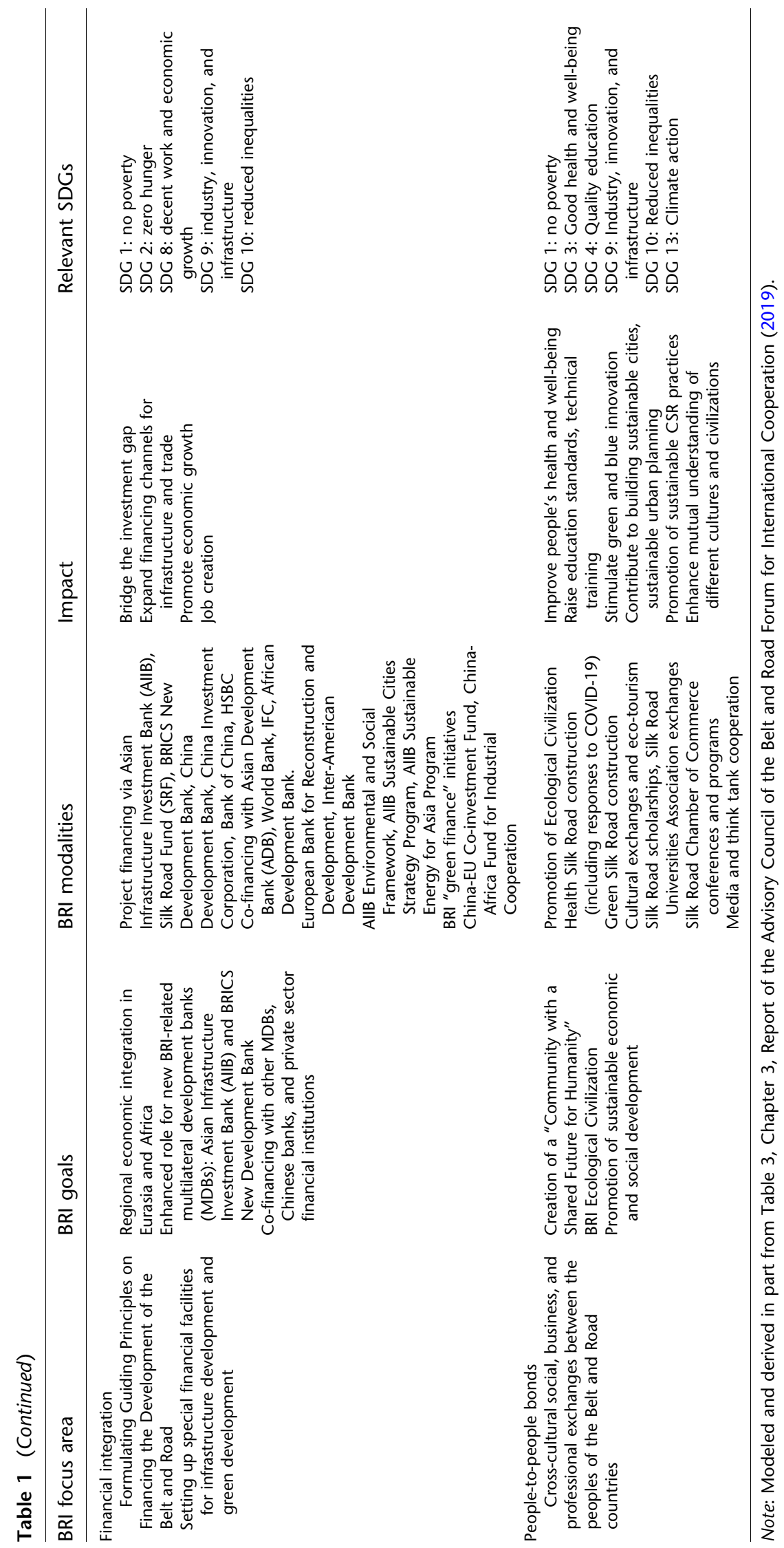


vision aligned with these goals - the Asian Development Bank (ADB) sees infrastructure as one of the main pillars of productivity growth (ADB, 2017) and the Asian Infrastructure Investment Bank (AIIB) has a clear focus on sustainable investment in this field, as further detailed below.

The inclusion of the Belt and Road within the framework of the UN sustainable development agenda (as discussed below) has the potential to create mutual positive synergies. First, BRI may have the capacity to become an accelerator for the rapid achievement of SDGs (Horvath, 2016; Pangu Think Tank, 2017). By promoting both economic growth and public welfare, BRI may serve as an effective interdependent institutional context for achieving sustainable development. BRI may also be an effective platform for mobilizing and integrating resources desperately needed for implementing SDGs around the world. Particularly important, via the financial and political support of China and other countries, BRI may help fill the yawning funding gap hampering the fulfillment of the SDGs - especially for less developed BRI countries. Second, the SDGs may also support BRI. The inclusion of the Belt and Road Initiative in the UN sustainable development framework may ensure that China remains a "responsible stakeholder" in global development cooperation and may minimize some of the negative fallout of geopolitical antagonism towards BRI. Likewise, the SDGs provide a focused agenda and specific targets to achieve many of BRI's goals. The participation of UN agencies and related organizations, in joint pursuit of the achievement of the SDGs with China, may in turn maximize BRI's positive impact and increase the acceptability of BRI globally.

Cooperation and coordination between China and UN agencies can be observed in the promotion of the 2030 Agenda and BRI. Beginning in 2016, China actively started communicating with the United Nations with a view to incorporating the Belt and Road into the UN's sustainable development framework. In April 2016, China signed a letter of intent with the United Nations Economic and Social Commission for Asia and the Pacific (UNESCAP) to jointly plan concrete actions to promote both BRI interconnectivity and strategic policy docking and pragmatic cooperation among BRI countries. In September 2016, China and the United Nations Development Program (UNDP) signed a memorandum of understanding on jointly promoting the construction of the Belt and Road, including many aspects of sustainable development. In November 2016, the UN General Assembly first recognized China's Belt and Road Initiative in one of its resolutions. In February 2017, the United Nations Commission for Social Development (UNCSD) adopted the "Social Aspects of the New Partnership for Africa's Development" resolution which for the first time acknowledged the BRI concept of a "Community of Common

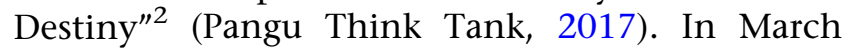
2017, the UN Security Council also expressed its support for BRI in UNSC Resolution 2344.

Recently, on 26 April 2019, the United Nations Secretary-General António Guterres emphasized that "the world will benefit from a Belt and Road Initiative that accelerates efforts to achieve the Sustainable Development Goals" and agreed that the "five pillars of the Belt and Road [...] are intrinsically linked to the 17 Sustainable Development Goals. These are conceptual pillars that can be translated into real-life progress for all people" (UN Press Release, 2019). The following five sections analyze the gradual convergence of BRI projects with the UN SDGs, as it is occurring in practice.

\section{SDGS INFLUENCE ON CHINA AND BRI}

China has officially committed to promoting a "civilization" of sustainability, as is shown in a range of major policy documents issued by, or developed under the leadership of, the Chinese government, particularly from 2015 to the present. China's approach to BRI takes the form of an elaborate network of international agreements and bilateral memoranda of understanding (MoUs) along development routes that branch out in the main areas of economic and social development. These branches are the maritime road, the land belt, and the Arctic, which focus on resources, connectivity, economic prosperity, and ecology closely matching the UN SDGs. In addition to statements made at the international level, China's commitment to sustainability is buttressed by national policy documents, such as the 13th and pending 14th Five Year Plans.

China has already taken major steps to mainstream sustainable development into BRI and its own national development plans - underlining the great importance China attaches to the implementation of the 2030 Agenda. In September 2016, the Chinese government officially released China's National Plan on Implementation of the 2030 Agenda for Sustainable Development - which integrates the 2030 Agenda and SDGs into its own national 
development strategy - and, in the international cooperation section of the document, into BRI as well.

The first action plan setting out the Vision and Actions on Jointly Building Silk Road Economic Belt and 21st-Century Maritime Silk Road (BRI Vision) (NDRC, MOFA \& MOFCOM, 2015) commits from the outset to sustainable development in the participating countries. BRI Vision approaches this from several angles. First, it looks at the economic element, by encouraging "ecological progress in conducting investment and trade". This is stated at both universal and local levels, by also emphasizing "localized operation and management of Chinese companies to boost the local economy, increase local employment, improve local livelihood." Second, it addresses the social element as it sets out the intention to improve education, health-care and "living conditions of poverty-stricken areas along the Belt and Road." Last but not least, it seeks to promote universal "cooperation in conserving ecoenvironment, protecting biodiversity, and tackling climate change."

Furthermore, China has demonstrated its commitment to sustainability in the current 13th Five Year Plan ("FYP") (2016-2020), pinpointing as major objectives the improvement of standards of living, quality of life, and quality of the environment. The philosophy of the proposed development further emphasizes the need for a green economy, a necessary condition for lasting reforms and overall well-being. The document also expressly mentions waste, which needs to be tackled through adopting a frugal lifestyle, conserving energy, and economical land use. The fight against poverty is accompanied by measures for achieving better education and public health - the latter being considered, since September 2017, an essential element of human rights (State Council of China, 2017). The 14th FYP (2021-2025), expected to be approved soon, is set to address carbon emission caps for the first time, in addition to targets for non-fossil fuel energy generation (Baxter \& Yao, 2019).

Of note, the current BRI Ecological and Environmental Cooperation Plan assigns a central role to enterprises, while corporate responsibility and transparency form the foundation of environmental governance (Ministry of Environmental Protection, 2017). In order to extend this effect, the policy also provides plans for developing ecologically based supply chains, which is bound to have even stronger impacts. Regarding the UN SDGs, China commits to achieving the goals by setting up timeframes for development: to 2025 for the six BRI economic corridors as the outlet for "concepts of ecological civilization", and to 2030, for in-depth implementation.

On the energy side, the BRI Energy Cooperation Vision put forward is still at an early stage, but nevertheless reinforces the characteristic BRI commitments (NDRC \& NEA, 2017). However, it does not address the concerns regarding carbon-based consumption or the continued use of fossil fuels, announcing only general principles. Strong and clear guidelines will be necessary, as the production and consumption of energy is of the essence to sustainability, and the very objective of SDG 7, which is focused on affordable and clean energy.

It is noteworthy that China has included sustainable investment as part of the G20 Guiding Principles for Global Investment Policymaking during its 2016 presidency, calling for coherence at national and international levels seeking to make policy "consistent with the objectives of sustainable development and inclusive growth."

\section{SDG IMPLEMENTATION CHALLENGES}

SDG implementation is facing major challenges and is behind schedule, despite the SDGs having been agreed to unanimously by 193 UN Members in 2015 (UN News, 2017). Multiple reasons have been posited for this situation. High on this list is the lack of sufficient funding for the SDGs - it has been estimated that the total cost for attaining all 169 targets could rise to $\$ 45$ trillion (Leitner \& Tillemann, 2017). Governments of developing countries are simply unable to foot the bill for the entire range of targets set by the 2030 Agenda. To effectively achieve the SDGs, a collaborative, responsive international architecture is required that must be capable of mobilizing and managing international aid, international development, philanthropy, impact investing, and foreign direct investment.

The SDGs have also been criticized as being too diverse and for failing to provide a clearly articulated sequencing of priorities (Leitner \& Tillemann, 2017), although it seems evident from the ordering of the SDGs that the total elimination of poverty (SDG 1) by 2030 remains the paramount goal. The SDGs have also been criticized as serving up the same time-worn models of neo-liberal economic development - which rely on economic growth as the panacea for the world's ills, even though such 
models inadequately capture social and community needs and are environmentally unsustainable for our planet. It has been further suggested that an annual GDP growth rate of $7 \%$ among the least developed countries will be necessary to achieve the SDGs by 2030 despite studies which show that growth alone does not necessarily spread economic benefits proportionately throughout society (Hickel, 2015), and which is currently being further hampered by the outbreak of COVID-19. This is a crucial area where BRI may strongly complement the SDGs given that China has cumulative pragmatic experience in growing its economy at double digits, with comparatively broad distribution of benefits across the population for many years in the past.

The recent UNESCAP SDG Progress Report, released in July 2019, warns that, unless progress is significantly accelerated, the Asia Pacific region is on course to miss all of the 17 SDGs and, with respect to some goals, the region is actually going backwards (UNESCAP, 2019). In particular, the SDGs related to access to clean water and sanitation (SDG 6), decent work and economic growth (SDG 8 ), and responsible consumption and production (SDG 11) are in retrograde motion.

China and the BRI may be able to shore up at least some of the deficiencies afflicting the SDGs (Horvath, 2016). China has raised tens of millions of its citizens out of poverty since the turn of the millennium. It has achieved such results through a combination of FDI utilization, state planning, and economic reform. To some extent, this formula is encapsulated in the so-called "Beijing Consensus" in which the State embraces innovation, experimentation, and incremental socio-economic reforms. In addition, China and BRI have access to numerous development funds, such as the Silk Road Fund and lending by the AIIB, which may contribute to the attainment of the SDGs. BRI presents an already-operational international architecture to help bring the SDGs to fruition.

\section{BRI CONTRIBUTIONS TO SDGS}

In addition to the BRI Energy Cooperation Vision document (2017) discussed above, the Chinese Ministry of Ecology and Environment has promulgated the BRI Ecological and Environmental Cooperation Plan (2017). This comprehensive roadmap contemplates the mutual recognition of sustainable infrastructure standards and the promotion of ecodesigned products and services, while also supporting green international trade and green finance instruments (IDDRI, 2019). China has also played a major role in the launch of an official $B R I$ International Green Development Coalition, together with UN Environment. During the second BRF in April 2019, three "operational" initiatives were also announced: the BRI Green Cooling Initiative; the BRI Green Lighting Initiative; and the BRI Green Going-Out Initiative for investments by Chinese companies abroad.

Another major BRI contribution to the SDGs is encapsulated in the Vision for Maritime Cooperation under the Belt and Road Initiative (MSR Vision, NDRC $\&$ SOA, 2017). According to MSR Vision, BRI social and economic development efforts will concentrate on building marine and maritime cooperation along so-called "blue economic passages" - which constitute a more concrete delineation of the 21st Century Maritime Silk Road. Such cooperation will entail coordinated "docking strategies" amongst BRI countries with a view to building joint platforms that focus on five priorities: (i) green development, (ii) ocean-based prosperity, (iii) maritime security, (iv) innovative growth, and (v) collaborative governance.

The first and foremost cooperative priority of the MSR Vision document is green development of the oceans, seas, and coastal areas that comprise the Maritime Silk Road. The overarching interest to be protected is the health of the ocean so as to foster improvements in human well-being for present and future generations. These goals echo SDG 14 - Life Below Water and SDG 3 - Good Health and WellBeing. BRI cooperation is proposed for purposes of marine ecological conservation, including safeguarding marine ecosystem health and biodiversity as well as promoting best practices to protect the BRI regional marine environment by specifically targeting problems such as marine pollution, marine litter, ocean acidification, coastal habitat destruction, and coral reef degradation.

Notably, sustainable investment and lending practices have begun to figure prominently in BRI programs and projects. The features of sustainable investment have been delineated in a study conducted by Sauvant and Mann (2017), which demonstrates that investment sustainability characteristics are not the same as general sustainability characteristics. Considering sustainable investment as "commercially viable investment that makes a maximum contribution to the economic, social, and environmental development of host countries and takes place in the framework of fair governance mechanisms," 
they analyze emerging characteristics from four perspectives: (i) economic, requiring community development and distribution of wealth; (ii) social, requiring, among others, protection of cultural heritage, fair wages and public health; (iii) environmental, requiring effective management of energy and pollution; and (iv) governance, requiring impact assessments and even anti-corruption. The fact that new traits emerge for sustainable investment is of particular importance because it implies a need for dedicated policies and reforms, whose efficiency and suitability must be evaluated separately. The findings also reveal a necessary sensitivity to the social element. This is an innovative approach as, traditionally, investment has been measured by reference to economic performance alone. Thus, this has managerial implications, requiring businesses to adapt at a micro level - a question on which we call for further research, per the section below.

In order to incentivize investment in the SDG direction, adequate funding conditional on compliance with sustainable policies is needed. The AIIB provides an example of promoting sustainability by only financing projects compliant with its environmental policy, which requires an environmental and social assessment and management of the proposed project. This is a change from the strategy adopted by other multilateral development banks such as the ADB, for instance, which operates a system of targets - i.e., for the 2013-2020 period, it aims to have $40 \%$ of its projects under the environmental sustainability theme.

Seeking to achieve sustainable and accessible infrastructure for all peoples, AIIB's core policy is the Environmental and Social Framework. Published in February 2016, the policy expressly refers to the SDGs, putting under the same umbrella the permanently linked notions of environmental and social sustainability, along with social development and inclusion. Gender equality, climate change (by reference to the Paris Agreement) and biodiversity are also listed individually as part of the vision. Implementation is ensured through field-based supervision. Strengthening of governance and corporate systems is also envisaged. Good performance is explicitly supported through incentives. In addition to involuntary resettlement and indigenous peoples policies, the social coverage includes assessment of the risks to vulnerable groups, genderspecific impact, land and natural resource access, and cultural resources. Working conditions are also assessed, with reference to health and safety, child labor and forced labor - the latter two being on the exclusion list of projects that will not be financed.

AIIB also has a Sustainable Cities Strategy, which answers the demands of urbanization and climate change, with a nod to natural disaster resilience. AIIB sees itself as being in a position of strength to support this initiative due to its capacity to finance directly governments, local authorities, and stateowned enterprises, but also by using private capital. The strategy has a short-term perspective of 3 years for a select group of cities, and a medium-term perspective of 5 years for cities with more demanding needs. AIIB's Sustainable Energy for Asia makes direct reference to the UN 2030 Agenda and SDG 7 (regarding affordable and clean energy), and the Paris Agreement.

\section{BRI IMPLEMENTATION CHALLENGES}

Many view BRI as advancing China's geopolitical, even hegemonic, ambitions in Eurasia and Africa, perhaps in line with its historical "tributary state system." U.S. formulation of a new Indo-Pacific strategy, the creation of a countervailing bloc known as the "Quad" (consisting of the United States, India, Japan, and Australia), and the AsiaAfrica Growth Corridor championed by India and Japan, represent examples of powerful, proactive resistance and opposition to these states' perception of BRI as the instrument of a geopolitical agenda (Singh, 2019). India, in particular, is adamantly opposed to the current iteration of BRI, which it regards as an "encirclement strategy" constituting unwarranted intrusion into the South Asian region. Recently, the U.S., as part of intensifying hostilities and rivalry with China, has strongly criticized BRI and urged countries to disengage from BRI projects. In such circumstances, there is a need for a strategic re-think of BRI, which can alleviate concerns and blunt the criticism of BRI through greater inclusiveness and pro-active international cooperation.

It is clear that, from China's perspective, BRI is intended to serve, perhaps predominantly, its international political and security interests. The Maritime Silk Road (MSR) is designed to secure unimpeded strategic access through the Straits of Malacca to the Indian Ocean and through the Red Sea to the Mediterranean. Port and zone construction, under BRI auspices, in Malaysia, Sri Lanka, Djibouti (China's first overseas naval base), and Egypt all serve China's security interests. This BRI emphasis on geopolitical security is further 
reinforced by China's network of "strategic partnerships" with BRI partners - China's equivalent of alliances (Lewis \& Moise, 2018), to the near exclusion of Western MNEs and local businesses as evidenced below.

It has been estimated that approximately $80 \%$ of BRI infrastructure projects funded by Chinese state banks have been awarded only to Chinese companies with European companies, in particular, acting merely as niche players (Devonshire-Ellis, 2018; European Union Chamber of Commerce in China, 2020). According to the Washington-based Center for Strategic and International Studies (CSIS), as of 2018, 89\% of contractors in Chinese-funded transportation projects, many of them BRI projects, are Chinese companies (Hillman, 2018). More than half of European companies in China that have bid on BRI-related projects list "insufficient information available" as a major challenge, while nearly $40 \%$ have struggled with "non-transparent public procurement systems" (European Union Chamber of Commerce in China, 2020). Clearly, there is an exigent need for greater inclusiveness of foreign business in BRI projects and for enhanced openness and transparency in the bidding and tendering process for such projects.

Nonetheless, certain foreign multinational corporations have been able to successfully position themselves to participate in BRI projects and related activities. Such MNE cooperation has taken the form of services provision and EPC (engineering, procurement, and construction) support arrangements often structured as joint ventures with Chinese companies (The Economist Intelligence Unit, 2018).

General Electric (GE) in the U.S. and Siemens AG, based in Germany, have both benefitted significantly from their participation in BRI projects. These MNEs have set up joint ventures with Chinese companies in BRI countries, providing technological support, equipment supply, and financial and operating solutions.

Notably, GE has entered into a MoU with the China National Machinery Industry Corporation to collaborate on clean energy projects in Sub-Saharan Africa. GE is also partnering with over 30 Chinese engineering, procurement, and construction (EPC) contractors in more than 70 markets in BRI countries, including collaborating on more than ten Pakistani power projects. For its part, Siemens is partnering with over 100 Chinese EPC contractors in more than 60 overseas markets (The Economist Intelligence Unit, 2018).
BRI partnerships with MNEs are also prevalent in regions where the Chinese presence is relatively recent and established MNEs have a comparative advantage. For example, Orange (formerly France Telecom) has teamed up with Chinese Internet giant Baidu to develop the mobile internet for Francophone Africa. Similarly, a consortium of French and Chinese firms, including French Bolloré and China Harbour Engineering Company (CHEC) have jointly won a bid to fund, build, and operate the Kribi Container Terminal in Cameroon (The Economist Intelligence Unit, 2018). Bolloré has also teamed up with CHEC and the Government of Timor-Leste in a PPP for the construction of the new Tibar Bay Container Port - intended to serve as an important BRI maritime trade hub between China and Oceania (Bolloré Ports, 2018).

Many BRI infrastructure projects are implemented through joint ventures and PPPs between Chinese firms and local private enterprises or government entities. Local partners are often indispensable to operate infrastructure and gain access to local markets as they possess the requisite connections with local authorities (The Economist Intelligence Unit, 2018). As is indicated in Table 2, BRI Projects (below), local private companies, in addition to local government entities, may perform a range of important functions as BRI project contractors, implementers, and operators. It should be noted that BRI projects with AIIB financial backing typically entail higher levels of local and foreign participation than projects without such multilateral support.

Local business participation in BRI projects may also take the form of state-owned enterprises, rather than private business. For example, in Indonesia, the Jakarta-Bandung High-Speed Rail project includes only Indonesian state-owned companies as lead contractors, and KCIC is the state-owned rail operator for the project. This is the Chinese preference. For BRI projects in Indonesia, Chinese loans are subject to certain conditions - the money must filter down to Indonesia's state-owned companies to provide a better fit with Chinese-participating SOEs (Devonshire-Ellis, 2018).

Nowhere perhaps is the challenge of aligning BRI strategies with SDG benchmarks more evident than in the CPEC, considered by China to be "the flagship project" for the entire BRI enterprise. Unlike the other economic corridors, which necessitate complex multilateral agreements, CPEC is an entirely bilateral arrangement built upon the foundation of over six decades of an "all-weather" 
strategic partnership between the two countries. Chinese investment in CPEC since 2014, estimated to ultimately reach $\$ 45-60$ billion, has targeted energy, communication, and transportation infrastructure, such as the Karot and Suki Kinari hydropower dams, the Peshawar-Lahore-Karachi railway, the port of Gwadar, a fiber optic project, and solar, wind, and coal-fired power plants (Fulton, 2018). Although there is potential for significant advances in all of the 17 SDGs, with China continuing to fund fossil fuel energy projects, even with steppedup investment in renewable energy, the "green" SDGs11-15 will probably remain elusive for some time to come.

As noted above, India remains skeptical of BRI as an intrusion on its regional prerogatives. If China is to refute these challenges and demonstrate the synergistic potentiality of BRI with the SDG framework, CPEC could be an important test case. In this regional context, BRI could serve as a vehicle both for addressing China's concerns over energy supplies and security, while also alleviating Pakistan's daunting economic and environmental problems, such as recurrent drought and desertification in Central and Southern Pakistan (Ferguson, 2018). Only time will tell, but particularly if CPEC can make headway in encouraging the rule of law, reducing violence (SDG 16), and enhancing stable cross-border partnerships (SDG 17), it will have made significant contributions toward creating a more stable and thus more sustainable sociopolitical environment. In a region that remains fraught with the potential for conflict, even to the point of a nuclear exchange, such stability is sorely needed.

In spite of the bilateral character of the CPEC, its high-speed rail, highway, pipeline, and port facilities now planned or under construction hold the potential for integrating a vast region, from the landlocked Central Asian nations to the north, to the Indian Ocean littoral as far as East and Southern Africa, the Persian Gulf, and Southeast Asia. The port of Gwadar conceivably could play a role akin to that of Hong Kong or Singapore, as a dynamic entrepot of regional commerce, linked to but not dominated by trade and investment from China. Should this occur, then fears of an overwhelmingly Sinocentric orientation of BRI may turn out to be misplaced, especially if Indo-Pakistani strategic competition and other simmering South Asian conflicts can be defused and turned in less militarized directions. Thus, while much of the infrastructural investment and construction in CPEC may be undertaken mainly by Chinese or joint Sino-Pakistani firms, the resultant infrastructure can serve much broader constituencies than its original funders and founders, just as the Suez Canal, the Inter-American Highway, or Japanese infrastructure projects (some undertaken many decades ago) in Southeast Asia do today.

\section{Japan's ASEAN Formula}

Japan's early experiences with FDI in the ASEAN countries could serve as a useful point of reference as China pursues a similar, albeit more extensive, outbound investment path via BRI today. In the 1980s, Japan, facing mounting trade frictions with the United States, began investing heavily in the Southeast Asian countries as external export platforms which were also attractive on account of their significantly lower production costs (Guisinger, 1991; Urata, 1993). Offshoring of Japanese manufacturing to ASEAN countries, especially in electronics, machinery, consumer goods, and later automobiles, made Japan's exports more competitive in Western developed countries and more affordable in newly emergent intra-ASEAN and wider East Asia markets. Japanese production arrangements typically involved electronics components being produced by a parent company in Japan or by Japanese subsidiaries in other developed countries or in the "Newly Industrialized Economies" (i.e., South Korea, Hong Kong, Singapore, and Taiwan) (Urata, 1993). These electronic components were then shipped to other Japanese subsidiaries in the ASEAN countries or back to the home country where final products such as TVs and refrigerators were assembled. Such cross-border business operations involved what is known today as the New International Division of Labor (NIDL). The ASEAN economies attracted Japanese FDI in manufacturing as they could provide the skilled labor necessary for industrial manufacturing processes.

The above was made possible by substantial infrastructure investment from the ADB, led and preponderantly financed by Japan, in the construction of roads, bridges, hydropower dams, and power plants and grids. Such ADB-financed infrastructure supported FDI by Japanese and non-Japanese MNEs in ASEAN, which, in turn, was a major factor underlying the development of Southeast Asia.

Recently, several BRI countries have cancelled or re-negotiated mega-projects or have balked at deepening their BRI relations with China, including Malaysia, Bangladesh, and Sri Lanka. It is noteworthy that the BCIM (Bangladesh, China, India, and Myanmar) Corridor, officially one of BRI's key components, was not referenced in the most recent Belt and Road Forum in Beijing in April 2019. It has been effectively replaced by the ChinaMyanmar Economic Corridor as a result of China's 
political, economic, and even military conflicts with its neighboring countries.

Many other criticisms have been leveled at BRI. U.S. Vice-President Pence and others have decried BRI as a vehicle for "debt-trap diplomacy" to ensnare unsuspecting BRI developing countries. From this perspective, Chinese financing of BRI infrastructure projects is viewed as a "deliberate strategy of entangling other developing countries in a web of debt, and then using this to extract unfair or strategic concessions" (Brautigam, 2019). Frequent reference has been made to the Hambantota port project in which the debt-encumbered Sri Lanka government ceded control over this new Indian Ocean port to a Chinese-dominated joint venture in return for $\$ 1.1$ billion investment. Similar concerns over the assumption of excessive debt recently led Prime Minister Mahathir of Malaysia to cancel and then re-negotiate BRI port and railway projects with China. Debt sustainability in developing BRI countries, especially in Africa, is no doubt a realistic concern. The IMF's Managing Director at the time, Christine Lagarde, warned that BRI poses risks of potentially failed projects and misuse of funds, which could lead to balance-ofpayments problems in developing countries and necessitate IMF bailouts (Brautigam, 2019). Recently, there has been a further assessment of China's BRI lending practices, which questions the underlying validity of elements of the Western "debt-trap" narrative (Brautigam, 2020).

The COVID-19 pandemic has effectively stalled BRI, as countries have sought to contain virus spread through travel bans and other transport and immigration restrictions disrupting, inter alia, trade, logistics, and the ability of skilled Chinese workers to return to BRI host countries. BRI developing countries are faced with severe debt-servicing difficulties and prospects of defaults on BRI-related loans. As a result, BRI projects have been put on hold and, in some cases, cancelled (The Economist, 2020). In order to re-galvanize BRI in the eventual post-COVID world, Beijing may have to provide developing countries with debt relief. Apparently, China has already begun this process, including through implementation of the G20 Debt Service Suspension Initiative (BRIX, 2020).

\section{BRI PROJECTS: IMPLEMENTING THE SDGS?}

Numerous BRI projects have already been launched in support of green development, both explicitly and implicitly, contributing to the attainment of the SDGs. The Silk Road Fund-supported Hassyan Clean-Coal Power Project in Dubai is deploying "ultra-supercritical technology" to meet the stringent industrial carbon emission standards of the European Union, while contributing to local environmental protection, energy savings, and emissions reductions. The SRF has also supported the Domestic-Waste-to-Energy Project in Vietnam, which collects 650 tons of household waste daily to generate $60,000,000 \mathrm{kWh}$ of green power annually, in full compliance with EU 2010 emissions standards. BRI-related institutions are also spearheading clean energy projects in Africa, Pakistan, Myanmar, Laos, among others, with the prospect of providing widespread people-centered access to affordable energy (Sheng, 2017).

In particular, the AIIB has approved and is funding numerous infrastructure projects in BRI countries, which are conducive to the attainment of specific SDGs. ${ }^{3}$ Many of these AIIB-funded projects focus on renewable energy development which positively supports, not only SDG 9 Industry, Innovation, and Infrastructure, but also SDG 7 - Affordable and Clean Energy, SDG 11 Sustainable Cities and Communities, and SDG 13 Climate Action. Such projects cover most forms of clean energy and include: Nepal's Upper Trishuli-1 Hydropower Project; Turkey's TKYB Renewable Energy and Energy Efficiency On-Lending Facility; the Kazakhstan Gulshat 40 MW PV Solar Power Plant; and Pakistan's UEP $100 \mathrm{MW}$ and Sachal 50 MW Wind Farms. Digital interconnectivity, in furtherance of China's Cyber/Digital Silk Road and supportive of SDGs 9 and 11, is also being funded by the AIIB - with flagship projects such as the Cambodia Fiber Optic Communication Network Project, Pakistan-China (CPEC) Fiber Optic Project, and Oman Broadband Infrastructure Project (AIIB Projects List, 2020) (see Table 2).

Looking at AIIB projects approved for funding, sovereign projects form the large majority. Out of the 18 non-sovereign approved projects funded entirely by AIIB (as of June 2020), 12 are financial in nature. One of the most notable is the recent Asia Climate Bond Portfolio, where AIIB partnered with Amundi (Europe's largest asset manager) for a multi-country non-sovereign financing project scheduled to begin investing in January 2020 (Silk Road Briefing, 2019). The project mobilizes US\$ 500 million with the purpose of improving the climate bond market. This is to be achieved by increasing finance flows for sustainable infrastructure in emerging markets, promoting climate change 
framework assessments and educating the markets with a view to improving the credit rating of eligible issuers.

Out of the six remaining non-sovereign projects, one of the largest is the Oman Broadband Infrastructure Project, a \$ 152.1 million project approved in December 2017. The borrower is Oman Broadband Company SAOC, a private company wholly owned by the Government of the Sultanate of Oman, incorporated in 2014 to implement a national policy to improve the broadband network in Muscat. In 2018, the Silk Road Fund has also pledged funds for this project, in participation with AIIB. As part of the financing, the Omani entity committed to sustainability by advancing an Environmental and Social Management Plan. While carrying out such an assessment is an AIIB requirement for funding, the plan also notes that it is the first study of this kind conducted for the project.

The private participation in AIIB funded projects is encouraging, although still in the minority. The international element of the projects is also noteworthy. Nevertheless, a green agenda pushed either through the public element of projects or simply through funding requirements and supervised compliance increases the likelihood of achieving SDGs. At this point in time, it is difficult to accurately assess implementation of these projects, but, as noted above, financial support combined with good compliance supervision has so far proved to be an effective measure.

In response to the COVID-19 pandemic, the AIIB has also authorized this year substantial emergency funding to the governments of the Philippines, Georgia, Bangladesh, India, and Indonesia. Such funding has been crucial in the fight against COVID-19 and serves the larger objectives of SDG 4 - Good Health and Well-Being - which has suddenly become an urgent global priority. Such AIIB actions undergird the re-emergence of the BRI Health Silk Road during the pandemic with the avowed purpose to "strengthen global public health governance" (Lancaster, Rubin, \& Rapp-Hooper, 2020). China has provided some 89 countries (including many BRI states) with essential PPE and ventilator supplies under the banner of the BRI Health Silk Road. China has been cooperating with another UN agency, the World Health Organization (WHO), to address global health challenges under the rubric of the Health Silk Road with some of its main features outlined at the BRF in 2017 (Tedros, 2017).

\section{COVID-19 and BRI Health Silk Road}

At the World Health Assembly 2020, President Xi identified certain elements of the Health Silk Road as part of the global response to COVID-19, while also linking it to building a "Community with a Shared Future for Humanity." Among these elements were the following:

- China will provide $\$ 2$ billion over 2 years to help with COVID19 response and with economic and social development in affected countries, especially developing countries;

- China will work with the UN to set up a global humanitarian response depot and hub in China, ensure the operation of antiepidemic supply chains, and foster "green corridors" for fasttrack transportation and customs clearance;

- China will establish a cooperation mechanism for its hospitals to pair up with 30 African hospitals and accelerate the building of the Africa CDC headquarters to help the continent ramp up its disease preparedness and control capacity (BRIX, 2020); and

- China will make its COVID-19 vaccine freely available to the whole world, once it passes clinical trials.

While such projects and initiatives suggest that China is embracing the SDGs, China has also been chided for pursuing BRI fossil fuel infrastructure development, especially coal-fired power plants, over renewable energy sources. During the first BRI investment wave (2014-2017), it has been reported that over $60 \%$ of Chinese energy sector FDI was directed towards investments in fossil fuels, mainly coal-powered projects, amounting to more than $\$ 20$ billion (IDDRI, 2019; The Guardian, 2019). Furthermore, construction projects use a significant proportion of critical natural resources, estimated at $50 \%$ of raw materials production and $80 \%$ of mineral raw materials production globally (Hoare, Hong and Hein, 2018). Thus, BRI's focus on infrastructure on the one hand, and the fact that it impacts $75 \%$ of the world energy reserves on the other (Freund \& Ruta, 2018), underlines the importance of SDG influence on both BRI policy and project implementation as some of these BRI infrastructure projects may need a long-term plan for moving toward "green" development.

The Chinese leadership appears to have become sensitized to the need to mitigate this proliferation of BRI fossil fuel projects and supports prioritization of BRI "green" renewable energy development, as exemplified by the BRI Ecological and Environmental Cooperation Plan (Ministry of Environmental Protection, 2017) discussed above. However, past and continuing Chinese FDI trends associated with BRI are disturbing. Certain elements of the Chinese 
government have explicitly supported Chinese companies moving their excess capacity abroad under the guise of "production cooperation," with BRI countries being identified as the most suitable relocation sites (Tracy, Shvarts, Simonov, \& Babenko, 2017). This has been coupled with China's own domestic "green shift" to a low-carbon economy and its embrace of ecological civilization - so that polluting and extractive industries are being transferred out of China to BRI developing countries. However, it is unlikely to be the case that all, or even most, of these outbound investments are actually "official" BRI projects. In particular, such pollution-causing investments do not appear on recognized BRI or AIIB project lists. Nonetheless, it would also appear that for some relocated polluting industries, such as coal-fired power plants and cement factories, their production may directly feed into or support "official" BRI projects.

The Chinese cement industry, in particular, has been cited as a prime example of this troubling trend. Among China's most polluting industries, the cement sector is notable for its detrimental impact on the environment, especially air pollution and carbon emissions, as well as outdated technologies and overproduction. Tajikistan, Laos, and Cambodia have been targets for Chinese cement sector relocation. In Tajikistan, for example, Chinese cement investments have led to a fivefold increase in cement production since 2010 (Tracy, Shvarts, Simonov, \& Babenko, 2017), which not only run counter to macro-level BRI goal alignment with the SDGs, but have also exacerbated legitimacy problems. Hu, Zhang, and Cook (2019) has reported cases of Chinese cement firms' investment in Cambodia and how these investment projects have resulted in damage to the local environment. However, the Chinese government and Chinese firms have subsequently assumed a greater commitment to CSR regimes and the SDGs through the adoption of enforcement and transparency measures. For instance, one of the largest Chinese cement producers, Huaxin Cement Corporation Ltd., the largest cement sector investor in Cambodia, now produces annual reports based on GRI's sustainable development reporting practices. ${ }^{4}$

A hallmark of the BRI Maritime Silk Road has been massive Chinese investments in Sri Lankan port projects, specifically, Hambantota Port, CICT (Colombo International Container Terminals), and Colombo Port City. Despite international criticism, particularly directed at BRI Hambantota Port, such mega-port projects in Sri Lanka have the potential to become bellwether examples of how BRI projects may concretely advance sustainable development and accelerate the fulfillment of the SDGs.

Hambantota Port Development is a billion-dollar-plus BRI project that aims to develop Hambantota International Port (HIP) into a world-class, advanced maritime center with global connectivity. In particular, HIP aspires to be a leading modern "green port" for the Indian Ocean region. As a BRI "green port," Hambantota is in an ideal position to adopt the UN's prescriptions concerning 2020 low sulfur cap emissions and to implement the UN International Maritime Organization (IMO) Internal GHG Strategy, which aims to decarbonize the maritime industry by 2100 (Ranaraja, 2020). There is considerable evidence of "green port" trends at Hambantota. In 2018, the Sri Lanka Board of Investments approved a \$500 million LNG plant to be constructed by China Machinery Engineering Corporation (CMEC), which is expected to provide substantial volumes of this less-polluting fuel for bunkering purposes in future. Even more significant has been the 2019 appointment of Chinese energy giant Sinopec as Hambantota's bunkering supplier. Sinopec is reportedly now ready to supply bunkers, including IMO 2020-compliant fuel, in particular, low sulfur fuel oil (LSFO) and marine gasoil (MGO), to Indian Ocean vessels (Taylor, 2019).

The CICT Terminal of Colombo Port, financed by China Merchant Port Holdings Company (CMPH) and completed in 2014, is currently the only stateof-the-art deep-water terminal in South Asia. The CICT Terminal explicitly prioritizes green technology - having switched to using electric cranes, thereby reducing overall carbon dioxide emission levels by $45 \%$ and diesel consumption levels by 95\%. Such crane engines emit zero carbon dioxide and minimal greenhouse gases (GHGs). Over 80\% of the electricity used in the operations of the CICT Terminal is reportedly generated using solar technology. The CICT Terminal is the most profitable of the four operational terminals of Colombo Port, contributing over $70 \%$ of Colombo Port's cargo volume, demonstrating that commercial success and environmental protection can go hand-inhand (Wignaraja, Panditaratne, Kannangara, \& Hundlani, 2020).

Colombo Port City, involving an initial Chinese investment of $\$ 1.3$ billion, represents another BRI port project in Sri Lanka guided by international green standards. The project is governed by a sustainability master plan, which aims to ensure 


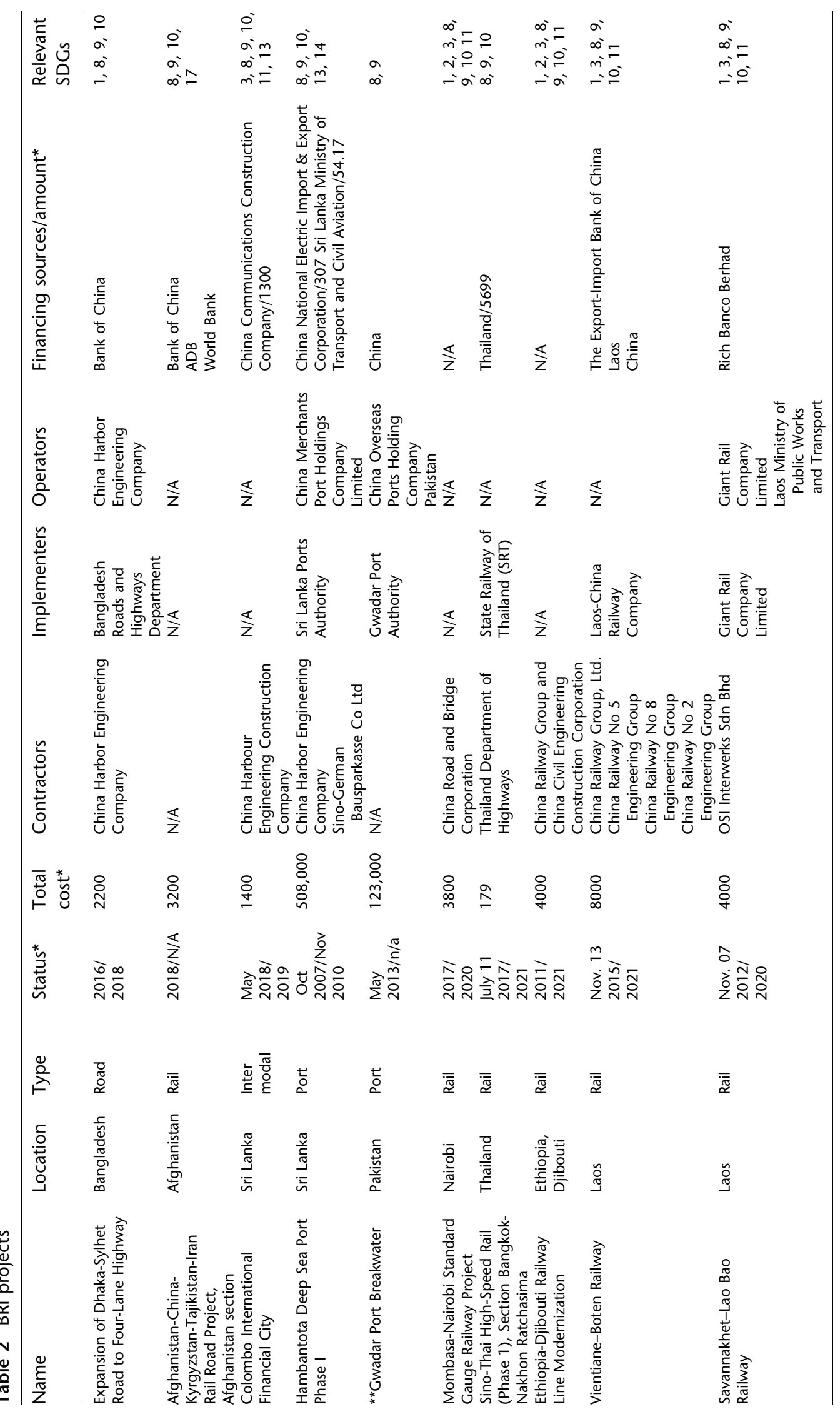




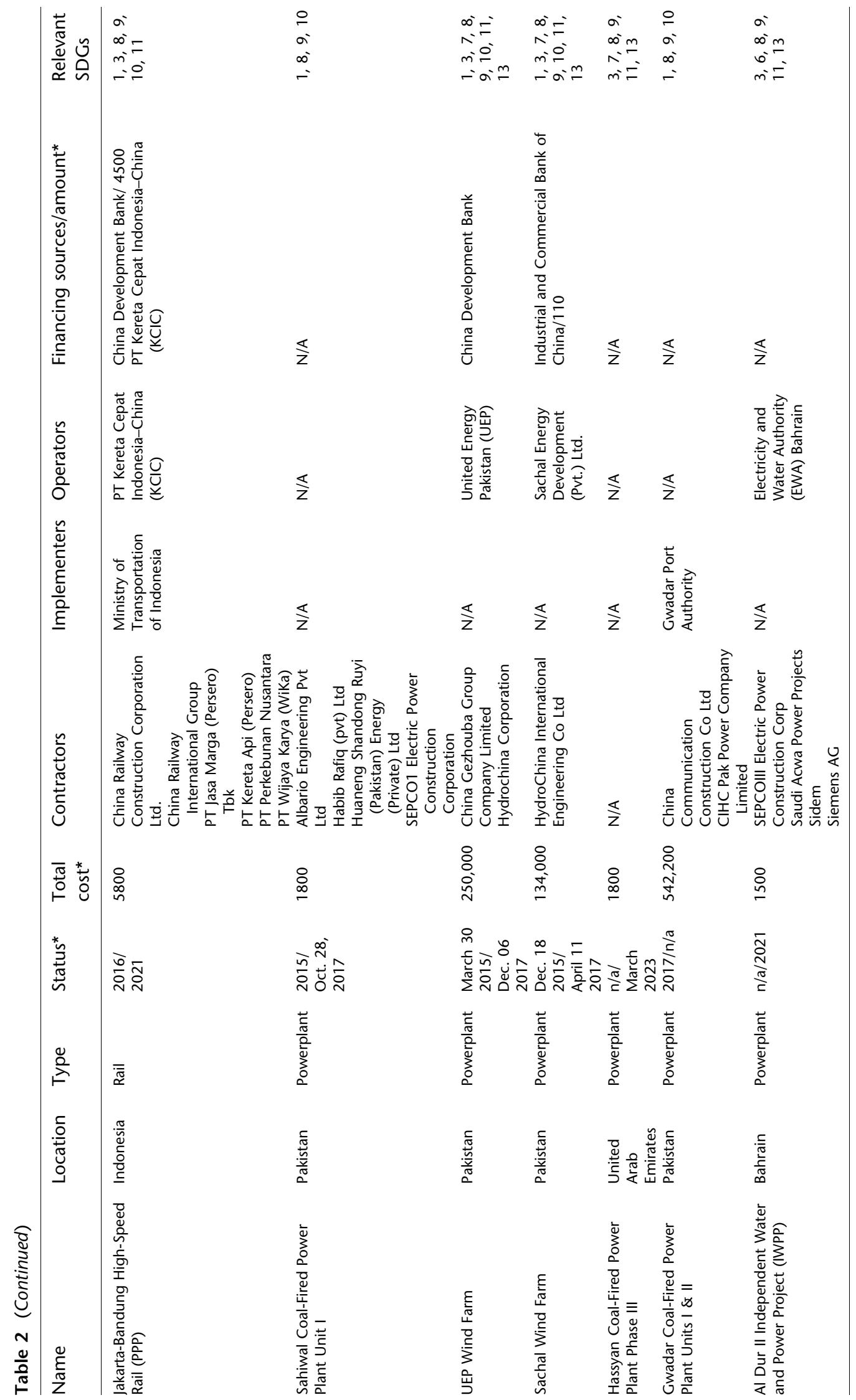




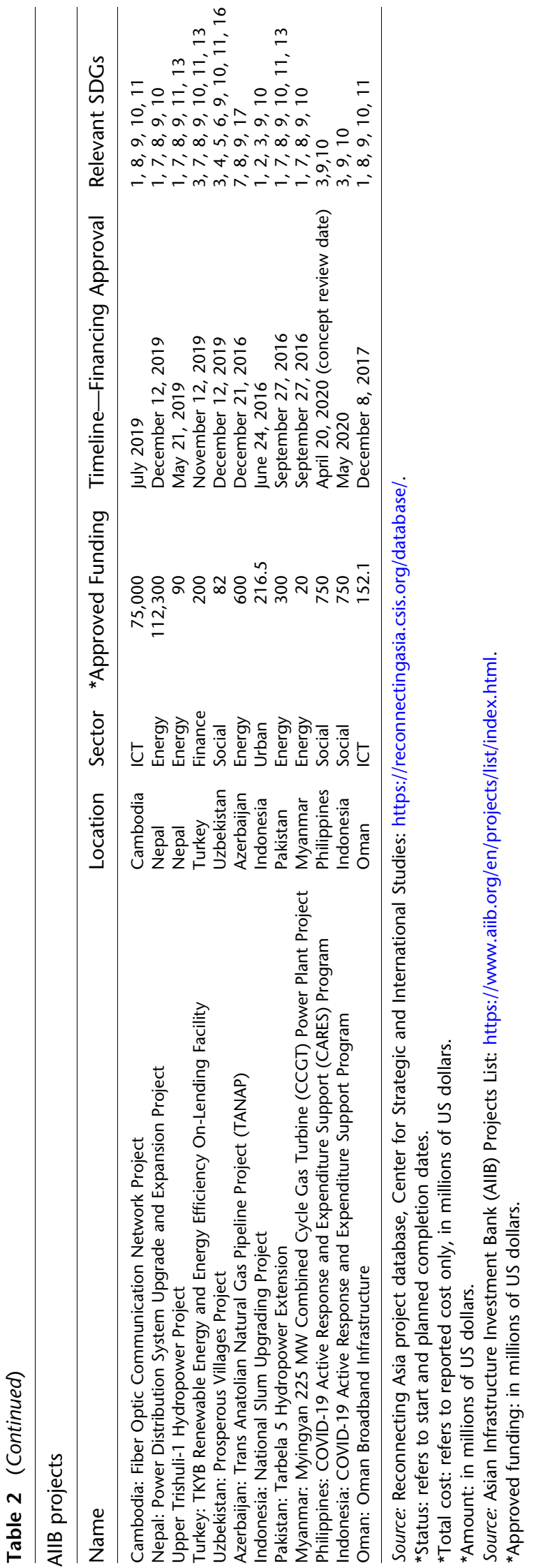

the overall design for construction and operations is in line with international best practices and benchmarks, including climate change adaptation and more specifically LEED, BREEAM, and Green Mark standards, while also ensuring that such actions meet green certifications from the Sri Lankan Green Building Council.

Consequently, Hambantota, along with CICT and Colombo Port City, are poised to contribute significantly to the advancement of the SDGs, especially SDG 13 - Climate Action and SDG 14 Life Below Water.

\section{DISCUSSION AND CONCLUSIONS}

Our study has sought to understand and document the intricate, dynamic, and interdependent relationships between the 17 SDGs and BRI goals and modalities. We have been able to identify a number of significant areas in which the SDGs have apparently influenced BRI and in which BRI has contributed to, or is supportive of, the SDGs. We conclude that BRI has the potential to contribute meaningfully over time to the substantial attainment of the 17 SDGs, which, in turn, should help to bolster the positive impact of BRI internationally.

While we see synergistic forces coalescing between the SDGs and BRI in many areas, especially infrastructure investment, the road ahead for further constructive alignment is fraught with major obstacles. Openness and inclusiveness remain as two looming, unresolved issues which are impeding BRI's potential to act as a dynamic accelerator for attainment of the SDGs. Until BRI-led Chinese infrastructure projects are open to meaningful participation by non-Chinese and local businesses, geopolitical tensions are unlikely to dissipate.

Our study makes contributions with respect to: (1) policymaking, (2) managerial practices, and (3) future research. We delineate them below.

\section{POLICY IMPLICATIONS}

With less than 10 years left before the UN 2030 Agenda is scheduled to be achieved, SDGs need all signatory member countries to pick up speed and strive to engage in both public and private sectors to invest in all 17 SDGs related areas. Boosters and accelerators to achieve the SDGs are greatly needed to ensure the timely achievement of the SDGs for the well-being of humanity. BRI, given its current frameworks, may potentially be one of the effective vehicles for achieving the SDGs on the ground through its relatively abundant funding and 
emphasis on infrastructure investment. In addition, China via BRI may be able to mobilize its partner countries to align their infrastructure investment projects with the SDGs to speed up the process.

China is clearly mainstreaming sustainable development and the achievement of the SDGs into its national economic development and BRI agendas. BRI already incorporates and promotes many of the SDGs. China's current national economic development plans and policies as well as BRI international institutions and practices support implementation of the SDGs. This is epitomized by China's 13th and pending 14th FYPs and, more specifically, China's 2016 National Plan on Implementation of the 2030 Agenda for Sustainable Development as well as the recent government report of Premier Li Keqiang delivered at the opening meeting of the third session of 13th National People's Congress on May 22, 2020. ${ }^{5}$ Aspects of the "greening of BRI" include the new area of "sustainable investment" and the current lending practices of the AIIB. Both the West and the East have arrived at the conclusion that sustainability is a priority. There is an exigent need to bridge views on SDGs and BRI shielded from the negative fallout of geopolitics, especially in light of the perilous state of U.S.-China relations poised on the brink of a new Cold War. Given the adverse publicity and perception of BRI, we believe that continuing convergence between BRI and the SDGs may help serve to alleviate public concerns about the legitimacy of BRI activities.

It is submitted that the formula of FDI, NIDL, and supporting infrastructure development financing is ideally suited to China's BRI infrastructure investment. NIDL, combined with targeted FDI, should be the primary vector for organizing development in the BRI countries. This combination will make it possible for a wide range of BRI countries to participate in China's industrial supply chains. China already has in place some of the essential components of this development strategy. China has established the AIIB - which as noted earlier - is providing critically needed infrastructure financing for BRI projects to benefit more countries and more corporate participants. China also has launched numerous "production cooperation" initiatives with BRI countries, notably Kazakhstan and Kyrgyzstan, which may be folded into comprehensive, multi-dimensional FDI-NIDL plans as part of longrange Eurasian and African regional integration strategy.
China has an unparalleled opportunity to incorporate the SDGs and sustainable development into its 21st Century FDI-NIDL formulations. NIDL should become a mechanism to introduce and transmit to BRI countries green technical solutions which have been incorporated into contemporary PRC manufacturing processes. This approach should result in BRI countries, via in-country affiliates with Chinese firms, being able to produce and export a range of green products, whilst also being exposed to Chinese-generated green technologies. In turn, such exposure and participation should reverberate throughout the host BRI country, engendering a pervasive green culture and economy, which can contribute substantially to the global attainment of the SDGs by 2030 .

The overt inclusion of BRI within the UN's 2030 Agenda is rapidly becoming a palpable reality with large implications for future studies of these two mega-initiatives and the pivotal role that international business can play. The BRI-SDGS Project, ${ }^{6}$ led by DESA and UNESCAP and sponsored by the UN Peace and Development Trust Fund (UNPDF) and the Chinese government, is intended to strengthen national capacity for a specified group of countries ${ }^{7}$ along the Belt and Road in order to assess and formulate coordinated integrative policies for international development cooperation under the Belt and Road initiative specifically to accelerate the achievement of the Sustainable Development Goals (SDGs) (Hong, 2017). BRI-SDGS consists of four components: (i) training and institutional networking of policymakers; (ii) broad policy dialogues; (iii) joint research and policy; and (iv) publication and dissemination. Notable events organized under these auspices include the workshop on "Assessing the Potential Impact of the Belt and Road Initiative on Sustainable Development Goals in Asian Economies" held in Bangkok in September 2019 and the December 2019 Silk Road Business Summit, which was convened in Xi'an by the Silk Road Chamber of International Commerce. At the summit, DESA BRI-SDGS chaired a session at a parallel forum and discussed how to promote international business engagement in the initiative with private and public representatives from over 30 countries. An outcome document, the Xi'an Consensus on Jointly Building an Open World Economy, was adopted by all participants at the close of the summit (Jointly Building Belt and Road towards SDGs, 2019).

BRI also helps to contextualize the SDGs so that these goals become more actionable within an 
institutional context (Van Zanten \& Van Tulder, 2018). We argue that an important vehicle for a more expansive and rigorous interpretation of the SDGs can be an evolving BRI policy. The contours of China's BRI policy are still being developed, but already include the important elements of a "Community with a Shared Future for Humanity" and ecological civilization - the latter, in particular, giving rise to an increasingly articulated policy discourse. Sustainability likewise provides an opportunity to adapt legal rules and institutions in favor of new social values, and therefore serves as a model for legal change in the BRI context. Ultimately, the internationalization of the BRI concept will not be feasible without policymakers understanding that it has to rely on the widely acknowledged realization that an ecological civilization is necessary for the sustainable future of humanity, the epitome of the UN's 2030 Agenda.

\section{MANAGERIAL IMPLICATIONS}

Sustainable investment is not just a buzzword: it is the future of the investment world - including infrastructure investment. A synergistic alignment between the SDGs and BRI may create substantial business opportunities for MNEs brought about by the UN's ambitious 17 SDGs and by China's national and BRI green and blue development initiatives. As calls for more openness and inclusivity are affirmatively answered, China is likely to promise extensive opportunities for non-Chinese and local businesses to participate in and profit from its green and blue development initiatives, including collaborative participation in the multistakeholder Belt and Road Green Development Partnership and BRI Blue Partnership. As infrastructure improves, we anticipate that the BRI countries will become more attractive destinations for global investors. MNEs from countries like the U.S. may achieve windfall gains by participating in BRI projects with their ownership advantages in management knowledge and critical technologies in infrastructure development, especially information technologies associated with the Cyber/Digital Silk Road (Yang, Lewis, Roddy \& Moise, 2018).

Clearly, it is in the best interests of Chinese MNEs to proactively factor the SDGs into their BRI corporate decision-making as some Chinese MNEs have been stigmatized for their poor CSR performance in local communities (Huang \& Zhu, 2016). Adopting the 17 SDGs in their CSR strategies provides an unprecedented opportunity for Chinese firms to rebrand themselves as well as integrating into the local communities. The 17 SDGs should spur Chinese firms to rethink their CSR strategies and to align their corporate strategies with achievement of such goals. Achieving SDGs potentially offers them the social and ethical foundation to operate in the host country, leading to greater legitimacy in the local community and stakeholder satisfaction while helping to engender greater accountability in Chinese MNEs. Hence, collaborative efforts and interoperable actions of international organizations (such as the UN agencies), MNEs, BRI national governments, and civil society are essential in order for the SDGs to pay back the stakeholders and to justify the 'social license to operate' (Doh, Husted \& Yang, 2016). More generally, the 17 SDGs could be a springboard for Chinese firms to rapidly build their global reputation in BRI countries as they create a new platform to build and improve corporate image and brand recognition.

\section{RESEARCH IMPLICATIONS}

There has been limited research on the interlinks between SDGs and BRI and MNE engagement with BRI, and almost none on how MNEs have adjusted their corporate strategy to take account of the 17 SDGs in the BRI context. This is not surprising given the restricted role of Western businesses in BRI projects as discussed above. While there have been solid studies conducted on Chinese OFDI, including to some extent on inter-connected relationships with BRI, studies of Chinese firm behavior have not focused much on how Chinese MNEs are adapting their management strategies to accommodate the SDGs, and national and supranational responses to the SDGs, in the BRI context. Generally, certain Chinese MNEs have apparently started reporting on their implementation of the 17 SDGs, including Haier and Huawei. Lack of understanding of such emerging trends in corporate behavior is bound to hamper policy development and effective realization of the 17 SDGs.

Future studies should also examine how increases in openness and inclusiveness may alter the nature of FDI projects and make-up of investor profiles, such as the ratio of Chinese and non-Chinese firms participating in BRI projects. It could also be illuminating to conduct comparative studies investigating similarities and differences in policies and outcomes between Japan's intertwined trade and investment patterns in Southeast Asia and those of China in BRI countries. Moreover, in anticipation of the burgeoning participation of Chinese and 
non-Chinese firms investing in economic activities of the BRI countries, the three pillars of environmental, social, and economic sustainability, the 17 SDGs, and the 169 targets will need to be comprehensively and holistically studied across all member countries and longitudinal studies should be conducted to systematically examine whether the synergies between the SDGs and BRI are positively correlated to the speed of SDG achievement in the BRI countries.

Our analysis has perhaps raised more questions than answers given that the phenomenon under study is relatively new and emerging and large systematic empirical datasets are lacking. With this study, we hope to stimulate interest among scholars across multiple disciplines and encourage research on the interplay between the SDGs and BRI rather than studying them in isolation.

Barring major unforeseen setbacks, we anticipate that the continuing convergence between these two mega-initiatives will bear significant fruit in the form of economic and sociopolitical development across Asia, Africa, and Europe in the mid- to long-term. Anticipating and adapting to these changes will present significant opportunities to both practitioners and researchers interested in understanding how sustainability principles can guide and transform national and regional development strategies. Moreover, should the openness, inclusivity, and localization practices we have addressed be accompanied by robust development of SDG implementation strategies by Chinese and other MNEs operating in BRI countries, along with a ramping down of geopolitical tensions, the synergies between the UN SDGs and BRI may ultimately succeed in transforming the world to a degree unprecedented in recent history.

\section{ACKNOWLEDGEMENTS}

We wish to thank the Editor-in-Chief Professor Sarianna Lundan and the special issue editors, especially Area Editor Professor Hafiz Mirza for his guidance and recommendations, which helped to improve our paper significantly. We also extend our thanks to Anne Hoekman, Managing Editor, for her guidance

\section{REFERENCES}

Advisory Council of the Belt and Road Forum for International Cooperation. 2019. Belt and Road Cooperation: for a better world, report on the findings and recommendations from the and support throughout the revision process. We particularly wish to thank all the participants and discussants at the Journal of International Business Policy Special Issue PDW at the AIB Annual Conference on June 24, 2019, in Copenhagen, Denmark, for their insights and suggestions. This paper was made possible by the generous financial support from the China Business Studies Institute (CBSI) at the University of San Francisco. Thanks are also due to CBSI student assistants Becky Tian and Earl $\mathrm{Xu}$ for their helpful assistance in preparing this manuscript. Last, but not least, we thank the anonymous reviewers for their time and effort to help us enhance the quality of the paper.

\section{NOTES}

${ }^{1}$ The SDGs consist of three pillars: environmental, social, and economic sustainability, 17 goals (the SDGs), and 169 targets associated with the goals.

${ }^{2}$ Now renamed: "A Community with a Shared Future for Humanity."

${ }^{3}$ It should be noted that only a proportion of AIIB projects are, technically speaking, BRI projects. We discuss in this section key AIIB sustainability projects in certain BRI countries. It is our view that AIIB projects are often complementary to BRI projects and supportive of BRI goals, such as regional connectivity and cooperation, in BRI countries.

${ }^{4}$ See Huaxin's annual CSR full reports: https:// www.huaxincem.com/shehuizeren/

shehuizerenbaogao.html.

${ }^{5}$ See full text of the report: http://english.www. gov.cn/premier/news/202005/30/content_ WS5ed197f3c6d0b3f0e94990da.html

${ }^{6}$ Formally entitled "Strengthening national policy capacity for jointly building the Belt and Road towards the Sustainable Development Goals."

${ }^{7}$ The current BRI-SDGS countries are: Azerbaijan, Bangladesh, Cambodia, Czech Republic, Georgia, Kazakhstan, Kyrgyzstan, Lao PDR, Mongolia, Myanmar, Romania, Serbia, Sri Lanka, and Thailand.

first meeting of the Advisory Council of the Belt and Road forum for international cooperation.

Asian Development Bank (ADB). 2017. Asian Development Outlook (ADO) 2017: Transcending the middle-income 
challenge.

https://www.adb.org/publications/asiandevelopment-outlook-2017-middle-income-challenge Accessed 2 October 2020.

Asian Infrastructure Investment Bank (AIIB) Projects List. https:// www.aiib.org/en/projects/list/index.html. Accessed 7 June 2020.

Baxter, T., \& Yao, Z. 2019. The 14th Five Year Plan: What ideas are on the table? China Dialogue.

Brautigam, D. 2019. Misdiagnosing the Chinese infrastructure push. The American Interest. https://www.the-americaninterest.com/2019/04/04/misdiagnosing-the-chineseinfrastructure-push/. Accessed 31 July 2019.

Brautigam, D. 2020. A critical look at Chinese 'debt-trap diplomacy': The rise of a meme. Area Development and Policy, 5(1): 1-14.

Belt and Road Institute in Sweden (BRIX). 2020. Health silk road updates. https://www.brixsweden.org/health-silk-roadupdates-3/?lang=en. Accessed 7 June 2020.

Bolloré Ports. 2018. Bolloré Ports launches construction of future Tibar port in Timor Leste. https://www.bollore-ports.com/en/ media/press-releases/bollore-ports-launches-construction-offuture-tibar-port-in-timor-leste.html. Accessed 2 October 2020.

Devonshire-Ellis, C. 2018. How foreign businesses can prosper from China's Belt and Road Initiative: Exploit the infrastructure. Silk Road Briefing. https://www.silkroadbriefing.com/ news/2018/04/30/foreign-businesses-can-prosper-chinasbelt-road-initiative-exploit-infrastructure/. Accessed 2 October 2020.

Doh, J., Husted, B.W. and Yang, X., 2016. Guest editors' introduction: Ethics, corporate social responsibility, and developing country multinationals. Business Ethics Quarterly, 26(3): 301-315.

European Union Chamber of Commerce in China. 2020. The road less travelled.

Feng, T., Kang, Q., Pan, B., \& Yi-sheng Yang, Y. 2019. Synergies of Sustainable Development Goals between China and countries along the Belt and Road Initiative. Current Opinion in Environmental Sustainability, 39: 167-186.

Ferguson, R. J. 2018. China's Eurasian Dilemmas: Roads and Risks for a Sustainable Global Power. Edward Elgar.

Freund, C., \& Ruta M. 2018. World Bank brief: Belt and Road Initiative. https://www.worldbank.org/en/topic/regionalintegration/brief/belt-and-road-initiative. Accessed 24 February 2019.

Fulton, J. 2018. The Gulf between the Indo-Pacific and the Belt and Road Initiative. Rising Powers Quarterly, 3(2): 175-193.

Geng, S. 2015. Building 'One Belt, One Road' to promote sustainable development. http://world.people.com.cn/n/ 2015/1117/c1002-27823807.html. Accessed 28 March 2019.

Guisinger, S. 1991. Foreign direct investment flows in East and Southeast Asia: Policy Issues. ASEAN Economic Bulletin, 8(1): 29-46.

Hamre J., Goodman, M., Gabel, J., and Hillman, J.E. 2020. Reconnecting Asia. Center for Strategic \& International Studies. https://reconnectingasia.csis.org/database/. Accessed 7 June 2020.

Hanson, Arthur. 2019. Ecological civilization in the People's Republic of China: Values, actions, and future needs. ADB working paper series no. 21 .

Hickel, J. 2015. The Problem with saving the world. https:// www.jacobinmag.com/2015/08/global-poverty-climatechange-sdgs/. Accessed 31 July 2019.

Hillman, J. E. 2018. China's Belt and Road Initiative: Five Years Later. Center for Strategic \& International Studies. https:// www.csis.org/analysis/chinas-belt-and-road-initiative-fiveyears-later-0. Accessed 2 October 2020.
Hoare A., Hong L., \& Hein J. 2018. The role of investors in promoting sustainable infrastructure under the Belt and Road Initiative. Chatham House.

Hong, P. 2016. People's daily international forum: 'One Belt, One Road' hand in hand with global Sustainable Development Goals. People's Daily Online.

Hong, P. 2017. Strengthening national policy capacity for jointly building the Belt and Road towards the Sustainable Development Goals. https://www.un.org/en/unpdf/assets/pdf/PDFSDG-2016-02\%20cdas_beltandroadb.pdf. Accessed 29 January 2020.

Horvath, B. 2016. Identifying development dividends along the Belt and Road Initiative: Complementarities and synergies between the Belt and Road Initiative and the Sustainable Development Goals. Scoping paper for UNDP. https://www. semanticscholar.org/paper/Identifying-Development-

Dividends-along-the-Belt-\%3A-Horv\%C3\%A1th/ a51cde3ec17824a59d20ec9c473de34cbcfe2b1e. Accessed 2 June 2020.

Hu, F., Zhang, F., \& Cook, D. L. 2019. Chinese enterprises' investment in infrastructure construction in Cambodia. Asian Perspective, 43: 177-207.

Huang, X., \& Zhu, Y. 2016. Managing Chinese outward direct investment: From entry strategy to sustainable development. London: Palgrave Macmillan.

IDDRI. 2019. Can the Belt and Road Initiative reinforce the multilateral agenda for sustainable development? https:// www.iddri.org/en/publications-and-events/blog-post/canbelt-and-road-initiative-reinforce-multilateral-agenda Accessed 31 July 2019.

Jointly Building Belt and Road towards SDGs. 2019. Regional workshop in Bangkok, jointly building Belt and Road towards SDGs September 2019 Updates. https://www.brisdgs.org/ jointly-building-belt-and-road-towards-sdgs-september-2019updates. Accessed 30 January 2020.

Lancaster, K., Rubin, M., \& Rapp-Hooper, M. 2020. Mapping China's health silk road. Council on Foreign Relations Blog. https://www.cfr.org/blog/mapping-chinas-health-silk-road. Accessed 7 June 2020.

Leitner, J., \& Tillemann, T. 2017. Why are the United Nations' Sustainable Development Goals stalling? https://psmag.com/ environment/why-are-the-uns-sustainable-developmentgoals-stalling. Accessed 31 July 2019.

Lewis, D., \& Moise, D. 2018. One Belt One Road ("OBOR") roadmaps: the legal and policy frameworks. In: Chaisse, J. and Górski, J. (eds.), The Belt and Road Initiative-Law, economics, and politics: 17-58. Leiden: Brill/Nijhoff.

Ministry of Environmental Protection. 2017. Belt and road ecological and environmental cooperation plan. https://www. followingthemoney.org/wp-content/uploads/2017/06/2017_ MEP_Belt-and-Road-Ecological-and-EnvironmentalCooperation-Plan_E.pdf. Accessed 14 June 2020.

National Development and Reform Commission, Ministry of Foreign Affairs, and Ministry of Commerce. 2015. Vision and actions on jointly building silk road economic belt and 21 stcentury maritime silk road. https://reconasia-production.s3. amazonaws.com/media/filer_public/e0/22/e0228017-746346fc-9094-465a6f1ca23/vision_and_actions_on_jointly_ building_silk_road_economic_belt_and_21st-century_ maritime_silk_road.pdf. Accessed 14 June 2020.

National Development and Reform Commission and the National Energy Administration. 2017. Vision and actions on energy cooperation in jointly building Silk Road Economic Belt and 21 st-Century Maritime Silk Road. https://reconasia-production.s3.amazonaws.com/media/filer_public/e0/22/ e0228017-7463-46fc-9094-0465a6f1ca23/vision_and_ac- 
tions_on_jointly_building_silk_road_economic_-

belt_and_21st-century_maritime_silk_road.pdf\#: :text $=$ The $\% 20$ Chinese $\% 20$ government $\% 20$ has $\% 20$ drafted,African\%20countries\%20more\%20closely\%20and. Accessed 14 June 2020.

National Development and Reform Commission and State Oceanic Administration. 2017. Vision for maritime cooperation under the Belt and Road Initiative. http://english.www. gov.cn/archive/publications/2017/06/20/content 281475691873460. htm. Accessed 14 June 2020.

Pangu Think Tank. 2017. Sustainable development prospects of 'One Belt, One Road'. https://economy.china.com/news/ 11173316/20170502/30480787.html. Accessed 18 March 2019.

Ranaraja, Y. 2020. Is Hambantota International Port better off with China? Seatrade Maritime News. https://www.seatrademaritime.com/opinions-analysis/hambantota-internationalport-better-china. Accessed 28 January 2020.

Sauvant K. P., \& Mann H. 2017. Towards an indicative list of FDI sustainability characteristics. http://e15initiative.org/ publications/towards-an-indicative-list-of-fdi-sustainabilitycharacteristics/. Accessed 14 June 2020.

Sheng, F. 2017. A sustainable look at the Belt and Road - Q\&A with Fulai Sheng. http://www.greengrowthknowledge.org/ blog/sustainable-look-belt-and-road-qa-fulai-sheng. Accessed 18 March 2019.

Sheng, J. (2020). The 'One Belt, One Road' initiative as regional public good: Opportunities and risks. Oregon Review of International Law, 21: 75-116.

Silk Road Briefing. 2019. AllB partners with Amundi to provide Asia climate bonds. https://www.silkroadbriefing.com/news/ 2019/09/18/aiib-partners-amundi-provide-asia-climatebonds/. Accessed 7 June 2020.

Singh, G. 2019. India, Japan and the Asia Africa growth corridor. https://www.gatewayhouse.in/japan-aagc/. Accessed 31 July 2019.

Taylor, I. 2019. Great expectations? Bunkerspot (June/July 2019). https://www.bunkerspot.com/features-all/item/greatexpectations-2. Accessed 30 January 2020.

Tedros, A. G. 2017. Towards a Health Silk Road. Belt and Road forum for health cooperation. https://www.who.int/dg/ speeches/2017/health-silk-road/en/. Accessed 7 June 2020.

The Economist. 2020. The pandemic is hurting China's Belt and Road Initiative. https://www.economist.com/china/2020/06/ 04/the-pandemic-is-hurting-chinas-belt-and-road-initiative. Accessed 7 June 2020.

The Economist Intelligence Unit. 2018. Participation of foreign firms in the BRI. https://www.business.hsbc.com/belt-and$\mathrm{road} /$ participation-of-foreign-firms-in-the-bri. Accessed 2 October 2020

The Guardian. 2019. Belt and Road summit puts spotlight on Chinese coal funding. https://www.theguardian.com/world/ 2019/apr/25/belt-and-road-summit-puts-spotlight-onchinese-coal-funding. Accessed 31 July 2019.

The State Council of China. 2017. State Council Information Office, white paper, development of China's public health as an essential element of human rights. http://english.gov.cn/ archive/white_paper/2017/09/29/content 281475894089810.htm. Accessed 19 December 2018.

Tracy, E. F., Shvarts, E., Simonov, E., \& Babenko, M. 2017. China's new Eurasian ambitions: the environmental risks of the Silk Road Economic Belt. Eurasian Geography and Economics, 58(1): 56-88.

UNCTAD. 2014. World Investment Report, Investing in the SDGs: An Action Plan. United Nations.

UN News. 2017. UN report urges accelerated efforts to achieve Sustainable Development Goals. https://news.un.org/en/ story/2017/07/561632-un-report-urges-accelerated-efforts-
achieve-sustainable-development-goals\#.WYoDuogrJaQ. Accessed 31 July 2019.

UN Press Release. 2019. United Nations poised to support alignment of China's Belt and Road Initiative with Sustainable Development Goals, secretary-general says at opening ceremony, SG/SM/19556, https://www.un.org/press/en/2019/ sgsm 19556.doc.htm. Accessed 10 lanuary 2020.

UNESCAP. 2019. Asia and the Pacific SDG progress report 2019. United Nations.

Urata, S. 1993. Japanese Foreign Direct Investment and Its Effect on Foreign Trade in Asia. Trade and Protectionism, NBER-EASE, vol. 2. Chicago: University of Chicago Press.

Van Zanten, J.A., \& Tulder, R. van. 2018. Multinational enterprises and the Sustainable Development Goals: An institutional approach to corporate engagement. Journal of International Business Policy, 1(3-4): 208-233.

Wignaraja, G., Panditaratne, D., Kannangara, P., \& Hundlani. D. 2020. Chinese investment and the BRI in Sri Lanka. Chatham House.

Yang, X., Lewis, D.J., Roddy, S. and Moise, D., 2018. One Belt, One Road, One World: Where is US Business Connectivity? In: Zhang, W., Alon, I., Lattemann, C. (eds.) China's Belt and Road Initiative (pp. 55-72). Palgrave Macmillan.

\section{ABOUT THE AUTHORS}

Donald J. Lewis is a Foreign Law Expert/Lecturer in the School of International Law at the China University Political Science and Law in Beijing and a Research Associate with the China Business Studies Initiative, School of Management, at the University of San Francisco. His research interests include: Chinese law, international trade and investment law, trade facilitation, and international dispute resolution.

Xiaohua Yang teaches International Business and heads the China Business Studies Initiative at the University of San Francisco. She received multiple best-paper awards from international conferences and three outstanding research awards from her School of Management. She has served as guest editor for Asia Pacific Journal of Management, Business Ethics Quarterly, Multinational Business Review, and Thunderbird International Business Review.

Diana Moise is a Trainee Associate at Debevoise \& Plimpton LLP in London. Her research interests include public international law, foreign investment, EU external relations and international dispute resolution. Diana holds degrees from University College London (LL.M.) and West University of Timisoara (LL.B.). 
Stephen Roddy is Professor and Chair of Modern \& Classical Languages at the University of San Francisco. His research focuses on premodern East Asian literary history and cross-border cultural exchange. He has recently held research fellowships at Sogang
University (Seoul), the National Library (Taipei), Nanjing University, Peking University, and the International Research Institute for Japanese Studies (Kyoto).

Publisher's Note Springer Nature remains neutral with regard to jurisdictional claims in published maps and institutional affiliations.

Accepted by Hafiz Mirza, Area Editor, 15 October 2020. This article has been with the authors for three revisions. 